Bangladesh J. Bot. 49(2): 229-236, 2020 (June)

\title{
GROWTH AND BIOMASS YIELD OF RUBBER SEEDLINGS GROWN ON SOILLESS AND SOIL-BASED MEDIA
}

\author{
Monsuru Adekunle Salisu, Zulkefly Sulaiman ${ }^{1}$ * And \\ MOHD YUSOFF ABD SAMAD ${ }^{2}$ \\ Department of Crop Science, Faculty of Agriculture, Universiti Putra Malaysia, 43400 UPM \\ Serdang, Selangor, Malaysia
}

Keywords: Growth, Biomass yield, Rubber seedlings, Soil-based medium

\begin{abstract}
The investigation assessed the performance of rubber seedlings on different soilless media and soilbased medium. The treatments consisted of three soilless media codded M1, M2, M3 and soil-based medium M4 as a control. The highest rates of seedling growth and biomass yield were recorded in the soilless medium with $10 \%$ burned rice husk (BRH), 30\% peat moss and $15 \%$ vermiculite (coded as M1) with noticeable effect in root morphological traits, while the $\mathrm{pH}$ and $\mathrm{EC}$ were 6.5 and $2.3 \mu \mathrm{S} / \mathrm{m}$, respectively. Nitrogen was apparent in the M1 2.59, M2 3.03, M3 2.78 while 1.82 in M4 was recorded in the soil-based medium. Similarly, the phosphorus was noticed in M1 0.23, M2 0.26, M3 0.33, and in M4 0.13. Plant roots of rubber seedlings grown in the M1 was significantly different from the seedlings grown in M2 and M3 and M4. The least amount (5\%) urea-N used was used in the best medium (M1). This amount of nitrogen could be maintained to reduce fertilizer usage. These results showed that the soilless medium that contains $10 \% \mathrm{BRH}$ with $5 \%$ urea$\mathrm{N}$ could greatly increase the growth of rubber seedlings.
\end{abstract}

\section{Introduction}

Plantation crops face some challenges because they are planted in ultisols and oxisols which are basically low in cation exchange capacity (Durham 1987). The challenges of the poor growth of rubber (Hevea brasiliensis L.) specially at nursery stage leads to plant death or long-term irreparable root and shoot damage due to the problems posed by the soils, alternative growing media are being widely considered in many parts of the world (Noordiana et al. 2007). Soilless medium increases higher plant densities per unit area and thereby effectively manage biological pest invasion/control. Use of soilless media equally reduces incidences associated with soil-borne diseases and pests which has led to reduce use of soil fumigant. Soilless media improves water efficiency and fertilizer uptake due to its high water holding and cation exchange capacity (Durner et al. 2002). Good physical and chemical properties of soilless media enable farmers to manipulate detrimental and unfertile soil conditions to enhance plant growth (Cantliffe et al. 2007). Noticeably, plant root damage is attributed to heavy soil or restriction of plant growth which leads to poor drainage and suppression of the plant root thereby exposes plants to soil-borne diseases.

On the other hand, many available soilless media for nursery trees, are reported not suitable for nursery plantation, especially in the tropics. Soilless media that would ensure adequate plant growth must have the following features viz., high porosity, good water holding capacity, free water draining properties, lightweight, free from growth-inhibiting elements, enrich with required

*Author for correspondence: <zulkefly@upm.edu.my>. ${ }^{1}$ Institute of Plantation Studies, Universiti Putra Malaysia, 43400 UPM Serdang, Selangor, Malaysia. ${ }^{2}$ Department of Land Management, Faculty of Agriculture, University Putra Malaysia, 43400 UPM Serdang, Selangor, Malaysia. 
nutrients and at the right $\mathrm{pH}$ (Mohanan and Sharma 2005). Under these circumstances, the study was aimed at providing alternative planting materials like soilless media to overcome the challenges of poor plant growth due to the low nutrients content of many tropical soils.

\section{Materials and Methods}

Two soilless media, commercial-based medium and munchong (oxisol) soil were used. The first medium composition (M1) contains $15 \%$ vermiculite, $5 \%$ perlite, $20 \%$ coconut husk, $10 \%$ compost, $30 \%$ peat moss and $10 \%$ BRH. Second medium (M2) contains $10 \%$ vermiculite, $10 \%$ perlite, $15 \% \mathrm{EFB}, 15 \%$, coconut husk, $20 \%$ peat moss and $15 \%$ sugarcane bagasse. The M1 and M2 were supplemented with Christmas Island rock phosphate (CIRP) and urea-N. A commercialbased soilless medium (coded as M3) was incorporated for comparison. Oxisol soil series was used as a control treatment (M4). In order to prepare the new soilless media, the materials were spread at the compost site of the University Putra Malaysia and mixed thoroughly. Bulk density of the soilless and soil media was determined by following the method described by Blake and Hartge (1986) as follow.

$$
\text { Bulk density }=\frac{\text { Weight of media, oven dried at } 105^{\circ} \mathrm{C} \text { ) }}{\text { Volume of fresh media }}
$$

The moisture content was determined in $\mathrm{g} / \mathrm{g}$ following the equation is given below.

$$
\text { Moisture content }=\frac{\text { Weight } \text { of fresh media }- \text { weight of oven dry media }}{\text { Weight of oven dry media }} \times 10
$$

Total porosity was determined by oven dried proportion of each of the media. A known quantity of the media in relation to the volume of the planting container used was calculated as follows:

$$
\text { Total porosity }=\left(1-\frac{\mathrm{Bd}}{\mathrm{Pd}}\right) \times 100
$$

where $\mathrm{Bd}$ is the bulk density and $\mathrm{Pd}$ is the particle density.

The saturated hydraulic conductivity of both soilless media and the soil was determined by following the method described by Teh and Jamal (2006). Nutrient elements of the media were extracted using a modified saturated medium extract using diethylenetriamine penta- acetic acid (DTPA) as described by Warncke (1990). N, P, K, Ca and Mg were analyzed using atomic absorption spectrometry (AAS) while the heavy metals were analyzed using inductively coupled plasma (ICP) mass spectrometry. Germination of RRIM 3001 rubber clone was carried out under a rain shelter using the respective media. Plant growth parameters including plant height and girth size, fresh and dry biomass were recorded. Root: shoot ratio was determined using the following equation:

$$
\mathrm{RSR}=\frac{\text { Total root dry weight }(\mathrm{g})}{\text { Total shoot dry weight }(\mathrm{g})}
$$

The seedlings quality (SQI) was determined using the Dickson quality index (DQI) (Dickson and Hosner 1960). It was calculated using the following equation:

$$
\mathrm{DOI}=\frac{\mathrm{TDM}(\mathrm{g})}{\frac{\mathrm{H}(\mathrm{cm})}{\operatorname{DIAM}(\mathrm{mm})} \vdash \frac{\mathrm{SDM}(\mathrm{g})}{\mathrm{RDM}(\mathrm{g})}}
$$


where $\mathrm{H}$ is the height values, DIAM collar diameter, SDM shoot dry mass, RDM root dry mass and TDM is the total dry matter.

The foliar analysis was carried out according to the rubber industry foliar sampling techniques as described by Noordin (2013). Root image analysis for root morphological traits such as length, average diameter, surface area, volume and number of root tips was carried out using WinRHIZO pro software (EPSON Perfection V700 Photo, Regent Instrument Inc. Canada). All data were analyzed using SAS Version 9.1. The least significant difference (LSD) was used to compare treatment means at the 0.01 and $0.05 \%$ probability levels.

\section{Results and Discussion}

Results of physicochemical properties of soilless and soil medium are presented in Table 1 . Bulk density was low $0.3 \mathrm{~cm}^{-3}$, suggesting good characteristics and easy handling compared to the soil (M4). All the media had high moisture content (MC) except soil with the lowest MC of 18.13 $\pm 0.7 \mathrm{~g} / \mathrm{g}$. This is in agreement with the studies conducted by Noordin (2013), who reported that both bulk density and MC determines the degree of its decomposition. Moreover, the value obtained is considered as suitable for greenhouse crops. Higher total porosity was recorded from 84.3 to $88.3 \%$, except in the soil-based medium which was recorded to be lower, $50.75 \%$. The soilless media could hold water almost twice higher than the soil and thereby minimizing stress to the plant under drought condition. The pH of the media were 5.48 (M1), 5.22 (M2), 6.42 (M3) and 4.20 (M4). The oxisol soil had the lowest $\mathrm{pH}$ and was more acidic. This was agreeable by the study conducted by Salisu et al. (2013). The value of EC varies among the soilless potting mix ranging from 0.57 to $1.83 \mathrm{Sm} / \mathrm{cm}$. This is in agreement with the previous report of the studies conducted by Miller (2001) on the chemical properties of soilless media. Most importantly the EC is within an acceptable range for the growth of Hevea brasiliensis (Miyamoto and Bucks 1985). Many crops grown in soilless media could survive within an acceptable EC $(<3.5 \mu \mathrm{S} / \mathrm{m})$.

M4 recorded the lowest of $\mathrm{C}: \mathrm{N}$ ratio while soilless media (M1, M2 and M3) had acceptable values for adequate plant growth. A high $\mathrm{C}: \mathrm{N}$ ratios could also aid fast decomposition of a medium and subsequently reduce growing medium volume. Soil M4 (Control) had the lowest total organic carbon (TOC) content 1.50\% while TOC of M1, M2 and M3 were 12.97, 22.27 and $15.83 \%$, respectively. The $\mathrm{N}$ was mostly present as organic $\mathrm{N}$ in the soil while $\mathrm{N}$ in soilless could be categorized as inorganic $\mathrm{N}\left(\mathrm{NH}^{4+}-\mathrm{N}\right.$ plus $\mathrm{NO}_{3}-\mathrm{N}$ ranged from 0.13 to $\left.6.47 \mathrm{mg} / \mathrm{l}\right)$. M1 recorded the highest CEC $(43.63 \mathrm{cmol}+/ \mathrm{kg})$ followed by M2 $(39.39 \mathrm{cmol}+/ \mathrm{kg})$ and soilless medium M3 $(34.77 \mathrm{cmol}+/ \mathrm{kg})$, while M4 had the lowest value $(20.50 \mathrm{cmol}+/ \mathrm{kg})$. M1 and M2 media relatively gave a better $\mathrm{CEC}$ value which was close to the requirement of many plants under greenhouse condition (Abad et al. 2002). The CEC was suitable for rubber seedlings. This is in agreement with the study conducted by Vieira et al. (2016) where RRIM 600 rubber seedling grown in the soilless substrate with $35 \mathrm{cmol}+/ \mathrm{kg}$ CEC performed better in almost all plant morphological traits than those grown in a soil-based medium. There was a significant difference among the plants grown in all the media (Table 2). The highest plant height was found on M1 $(25.40 \mathrm{~cm} / \mathrm{plant})$ and significantly different from the plants grown in M2 $(19.6 \mathrm{~cm} / \mathrm{plant})$ and M3 $(21.4 \mathrm{~cm} /$ plant). A similar scenario was recorded on plant stem diameter.

The number of leaves was significantly affected by the soilless media. The number of leaves of plant growing in M1 (33.80) and M2 (29.40) media were significantly $(\mathrm{p}=<0.0001)$ greater than those grown in M3 (18.80) and M4 (16.20) soil (control) media. The performance of M1 and M2 media on the number of leaves may be due to the combination of materials used in both media. This is supported by Hirel et al. (2001) who stated that media containing peat moss, vermiculite, and perlite increased the number of leaves of greenhouse plants and could similarly influence on 
other growth traits. Leaf area of plants $\left(720.66 \mathrm{~cm}^{2} /\right.$ plant $)$ grown in M1 was significantly different $(P=0.0003)$ from plants grown in other media. There was a significant difference $p<0.05$ among the media in terms of chlorophyll content of leaves of rubber seedlings with a better influence on plants grown on M1 and M2. However, Sharma et al. (2015) reported a strong relationship between chlorophyll content and leaf area. Results of biomass yield of the rubber seedling are shown in Table 3. M1 medium greatly increased shoot fresh weight $(22.14 \mathrm{~g} / \mathrm{plant})$ and the value was significantly $(\mathrm{p}=0.0001)$ different from M2 (15.67 g/plant), M3 (5.09 g/plant) and M4 (6.65 g/plant).

Table 1. Physico-chemical properties of the soilless and soil-based media.

\begin{tabular}{|c|c|c|c|c|}
\hline Physical properties \pm SE & M1 & M2 & M3 & M4 \\
\hline Bulk density $\left(\mathrm{cm}^{3}\right)$ & $0.3 \pm 0.01$ & $0.3 \pm 0.01$ & $0.30 \pm 0.01$ & $1.67 \pm 0.32$ \\
\hline Moisture content (g/g) & $65.3 \pm 0.93$ & $140.3 \pm 0.9$ & $143.45 \pm 0.6$ & $18.13 \pm 0.7$ \\
\hline Total porosity (\%) & $88.3 \pm 0.23$ & $84.3 \pm 2.73$ & $85.04 \pm 3.1$ & $50.75 \pm 0.8$ \\
\hline Hydraulic conductivity $(\mathrm{cm} / \mathrm{hr})$ & $26.2 \pm 0.60$ & $3.6 \pm 0.42$ & $33.50 \pm 0.76$ & $10.28 \pm 0.4$ \\
\hline Saturation $\left(\mathrm{m}^{3} / \mathrm{m}^{3}\right)$ & $0.8 \pm 0.01$ & $0.7 \pm 0.02$ & $0.79 \pm 0.01$ & $0.32 \pm 0.01$ \\
\hline Field Capacity $\left(\mathrm{m}^{3} / \mathrm{m}^{3}\right)$ & $0.7 \pm 0.01$ & $0.7 \pm 0.08$ & $0.64 \pm 0.03$ & $0.22 \pm 0.01$ \\
\hline Permanent wilting point $\left(\mathrm{m}^{3} / \mathrm{m}^{3}\right)$ & $0.4 \pm 0.01$ & $0.3 \pm 0.01$ & $0.44 \pm 0.01$ & $0.14 \pm 0.01$ \\
\hline Available water $(\%)$ & $0.3 \pm 0.02$ & $0.3 \pm 0.01$ & $0.22 \pm 0.01$ & $0.45 \pm 0.19$ \\
\hline \multicolumn{5}{|l|}{ Chemical Properties } \\
\hline $\mathrm{pH}$ & $5.48 \pm 0.01$ & $5.22 \pm 0.01$ & $6.42 \pm 0.03$ & $4.20 \pm 0.06$ \\
\hline $\mathrm{EC}(\mu \mathrm{S} / \mathrm{m})$ & $1.45 \pm 0.02$ & $1.83 \pm 0.01$ & $0.60 \pm 0.01$ & $0.57 \pm 0.38$ \\
\hline $\mathrm{CEC}(\mathrm{cmol}+/ \mathrm{kg})$ & $43.63 \pm 0.72$ & $39.39 \pm 0.61$ & $34.77 \pm 0.61$ & $20.50 \pm 0.6$ \\
\hline TOC \% & $12.97 \pm 0.27$ & $22.27 \pm 0.64$ & $15.83 \pm 0.52$ & $1.50 \pm 0.06$ \\
\hline$C: N$ & $13.67 \pm 0.88$ & $21.00 \pm 0.58$ & $15.67 \pm 0.88$ & $4.33 \pm 0.33$ \\
\hline $\mathrm{N}(\mathrm{mg} / \mathrm{l})$ & $4.73 \pm 0.69$ & $6.47 \pm 0.34$ & $4.10 \pm 0.06$ & $0.13 \pm 0.01$ \\
\hline P " & $0.24 \pm 0.03$ & $4.33 \pm 0.12$ & $0.31 \pm 0.01$ & $23.33 \pm 0.9$ \\
\hline $\mathrm{K}^{+}(\%)$ & $0.31 \pm 0.01$ & $0.77 \pm 0.04$ & $3.77 \pm 0.09$ & $0.86 \pm 0.04$ \\
\hline $\mathrm{Ca}^{+} "$ & $1.77 \pm 0.04$ & $5.20 \pm 0.11$ & $1.32 \pm 0.01$ & $0.24 \pm 0.03$ \\
\hline $\mathrm{Mg}^{2+} "$ & $0.30 \pm 0.01$ & $1.40 \pm 0.01$ & $0.21 \pm 0.01$ & $1.57 \pm 0.04$ \\
\hline $\mathrm{Zn} "$ & $0.11 \pm 0.01$ & $0.13 \pm 0.01$ & $9.53 \pm 0.38$ & $0.04 \pm 0.01$ \\
\hline $\mathrm{Cu} "$ & $0.04 \pm 0.01$ & $0.11 \pm 0.01$ & $0.14 \pm 0.01$ & $0.32 \pm 0.24$ \\
\hline Mn " & $0.33 \pm 0.01$ & $0.31 \pm 0.01$ & $7.72 \pm 0.02$ & $1.16 \pm 0.09$ \\
\hline $\mathrm{Pb} "$ & $0.14 \pm 0.03$ & $0.20 \pm 0.06$ & $0.13 \pm 0.09$ & $0.10 \pm 0.05$ \\
\hline $\mathrm{Cd} "$ & $0.02 \pm 0.01$ & $0.50 \pm 0.06$ & $0.10 \pm 0.05$ & $0.02 \pm 0.01$ \\
\hline $\mathrm{Cr} "$ & $0.77 \pm 0.09$ & $0.60 \pm 0.25$ & $0.20 \pm 0.06$ & $0.22 \pm 0.01$ \\
\hline B " & $0.10 \pm 0.05$ & $0.05 \pm 0.03$ & $0.53 \pm 0.15$ & $0.12 \pm 0.01$ \\
\hline $\mathrm{Fe} "$ & $0.30 \pm 0.06$ & $1.12 \pm 0.01$ & $4.70 \pm 0.06$ & $1.14 \pm 0.02$ \\
\hline
\end{tabular}

$\mathrm{EC}=$ Electric conductivity, $\mathrm{CEC}=$ Cation exchange capacity and $\mathrm{TOC}=$ Total organic carbon.

Similarly, M1 significantly affected root dry weight (1.89 g/plant) and significantly higher $(\mathrm{P}=0.0049)$ than the seedlings grown in $\mathrm{M} 2(0.80 \mathrm{~g} / \mathrm{plant})$ and $\mathrm{M} 3$ media $(0.70 \mathrm{~g} / \mathrm{plant})$. All the growing media except M2 significantly increased seedling quality index (SQI) of the plants p < 
0.05 . The growing medium M1 and M2 had a highly significant $(\mathrm{p}=<0.0001)$ effect on total fresh weight (TFW) of rubber seedlings at $32.5 \mathrm{~g} / \mathrm{plant}$ and $21.8 \mathrm{~g} / \mathrm{plant}$, respectively. This is supported by the study conducted by Kim and $\mathrm{Li}$ (2016) who observed that perlite-based potting media greatly affects plant growth and noticeable in both root and shoot dry weight. Furthermore, M1 and M2 media had a highly significant effect $(\mathrm{p}=<0.0001)$ on plant total dry weight, $9.83 \mathrm{~g} / \mathrm{plant}$ and $5.36 \mathrm{~g} /$ plant respectively, which was significantly different from the plants growing in other tested media. Physical properties of the medium equally influence the other vegetative like the shoot fresh and dry weight as well as the ratio of root to shoot (Sinclair and Vadez 2002).

Table 2. Growth of rubber seedlings grown in the soilless potting mix and soil-based medium.

\begin{tabular}{llllll}
\hline Treatments & $\begin{array}{l}\text { Av. plant } \\
\text { height } \\
(\mathrm{cm})\end{array}$ & $\begin{array}{l}\text { Av. stem } \\
\text { diameter } \\
(\mathrm{mm})\end{array}$ & $\begin{array}{l}\text { Number of } \\
\text { leaves/plant }\end{array}$ & $\begin{array}{l}\text { Leaf area } \\
\left(\mathrm{cm}^{2} / \text { plant }\right)\end{array}$ & $\begin{array}{l}\text { Chlorophyll } \\
\text { content of leaves } \\
(\mathrm{mV})\end{array}$ \\
\hline $\mathrm{M} 1$ & $25.40 \mathrm{a}$ & $5.54 \mathrm{a}$ & $33.80 \mathrm{a}$ & $720.66 \mathrm{a}$ & $27.75 \mathrm{a}$ \\
$\mathrm{M} 2$ & $19.6 \mathrm{~b}$ & $3.82 \mathrm{~b}$ & $29.40 \mathrm{a}$ & $231.21 \mathrm{~b}$ & $26.05 \mathrm{a}$ \\
$\mathrm{M} 3$ & $21.4 \mathrm{~b}$ & $3.77 \mathrm{~b}$ & $18.80 \mathrm{~b}$ & $84.63 \mathrm{~b}$ & $17.23 \mathrm{ab}$ \\
$\mathrm{M} 4$ & $23.0 \mathrm{ab}$ & $3.12 \mathrm{~b}$ & $16.20 \mathrm{~b}$ & $136.89 \mathrm{~b}$ & $14.09 \mathrm{~b}$ \\
$\mathrm{LSD}_{5 \%}$ & 3.84 & 0.80 & 5.510 & 168.29 & 11.04 \\
$\mathrm{p}>\mathrm{F}$ & 0.0371 & 0.0002 & $<.0001$ & 0.0003 & $<0.05$ \\
\hline
\end{tabular}

Mean values followed by the same letter within the same column are not significantly different at $\mathrm{p}<0.05$, based on a least significant difference test (LSD).

Table 3. Plant biomass yield and seedling quality index (SQI) of rubber seedlings.

\begin{tabular}{lllllllll}
\hline Treatments & $\begin{array}{l}\text { SFW } \\
(\mathrm{g})\end{array}$ & $\begin{array}{l}\text { RFW } \\
(\mathrm{g})\end{array}$ & $\begin{array}{l}\text { SDW } \\
(\mathrm{g})\end{array}$ & $\begin{array}{l}\text { RDW } \\
(\mathrm{g})\end{array}$ & $\begin{array}{l}\text { TFW } \\
(\mathrm{g})\end{array}$ & $\begin{array}{l}\text { TDW } \\
(\mathrm{g})\end{array}$ & $\begin{array}{l}\text { SQI } \\
(\mathrm{DQI})\end{array}$ & RSR \\
\hline M1 & $22.14 \mathrm{a}$ & $10.35 \mathrm{a}$ & $7.93 \mathrm{a}$ & $1.89 \mathrm{a}$ & $32.5 \mathrm{a}$ & $9.83 \mathrm{a}$ & $1.104 \mathrm{a}$ & $8.88 \mathrm{a}$ \\
$\mathrm{M} 2$ & $15.67 \mathrm{~b}$ & $6.09 \mathrm{~b}$ & $4.55 \mathrm{~b}$ & $0.80 \mathrm{~b}$ & $21.8 \mathrm{~b}$ & $5.36 \mathrm{~b}$ & $0.75 \mathrm{~b}$ & $3.74 \mathrm{~b}$ \\
$\mathrm{M} 3$ & $5.09 \mathrm{c}$ & $2.92 \mathrm{c}$ & $2.28 \mathrm{c}$ & $0.70 \mathrm{~b}$ & $8.02 \mathrm{c}$ & $2.99 \mathrm{c}$ & $1.002 \mathrm{ab}$ & $1.50 \mathrm{~b}$ \\
$\mathrm{M} 4$ & $6.65 \mathrm{c}$ & $3.06 \mathrm{c}$ & $1.24 \mathrm{c}$ & $1.26 \mathrm{ab}$ & $9.70 \mathrm{c}$ & $2.41 \mathrm{c}$ & $1.24 \mathrm{a}$ & $2.32 \mathrm{~b}$ \\
$\mathrm{LSD}$ & 2.67 & 2.91 & 1.76 & 0.89 & 4.3459 & 2.17 & 0.34 & 4.52 \\
$\mathrm{p}>\mathrm{F}$ & $<0.0001$ & 0.0005 & $<0.0001$ & 0.049 & $<0.0001$ & $<0.0001$ & 0.05 & 0.026 \\
\hline
\end{tabular}

Mean values followed by the same letter within the same column are not significantly different at $\mathrm{p}<0.05$, based on a least significant difference test (LSD). SFW $=$ Shoot fresh weight, RFW $=$ Root fresh weight, SDW $=$ Shoot dry weight, RDW $=$ Root dry weight, TFW $=$ Total fresh weight, TDW $=$ Total dry weight, $\mathrm{SQI}=$ Seedling quality index and RSR = Root : shoot ratio.

Results of the foliar nutrient analysis are presented in Table 4. Each of the soilless media significantly influenced the nutritional status of the rubber seedlings. Nitrogen concentration in plants grown in $\mathrm{M} 2(3.03 \%)$ was significantly $(\mathrm{P}=0.002)$ higher than what was found in plants grown in M1 (2.59\%) and M4 (1.82\%). 
Table 4. Foliar nutrient concentration of rubber seedlings grown in soilless media and soil-based medium.

\begin{tabular}{llllll}
\hline Treatments & $\mathrm{N}$ & $\mathrm{P}$ & $\mathrm{K}$ & $\mathrm{Ca}$ & $\mathrm{Mg}$ \\
$(\%)$ & $(\%)$ & $(\%)$ & $(\%)$ & $(\%)$ \\
\hline M1 & $2.59 \mathrm{~b}$ & $0.23 \mathrm{~b}$ & $1.06 \mathrm{~b}$ & $0.80 \mathrm{a}$ & $0.19 \mathrm{a}$ \\
M2 & $3.03 \mathrm{a}$ & $0.26 \mathrm{~b}$ & $0.99 \mathrm{bc}$ & $0.84 \mathrm{a}$ & $0.19 \mathrm{a}$ \\
M3 & $2.78 \mathrm{ab}$ & $0.33 \mathrm{a}$ & $1.26 \mathrm{a}$ & $0.77 \mathrm{a}$ & $0.20 \mathrm{a}$ \\
M4 & $1.82 \mathrm{c}$ & $0.13 \mathrm{c}$ & $0.82 \mathrm{c}$ & $0.68 \mathrm{~b}$ & $0.10 \mathrm{~b}$ \\
LSD & 0.42 & 0.0344 & 0.18 & 0.093 & 0.05 \\
$\mathrm{p}>\mathrm{F}$ & 0.002 & $<0.0001$ & 0.006 & 0.0220 & 0.0055 \\
\hline
\end{tabular}

Mean values followed by the same letter within the same column are not significantly different at $\mathrm{p}<0.05$, based on a least significant difference test (LSD).

Similarly, the phosphorus concentration in all the tested media was significantly higher than the control, M4 (0.13\%) soil. Noticeably, the plants grown in M3, the commercial soilless medium recorded the highest value of the $\mathrm{P}$ content $0.33 \%$. The concentrations of $\mathrm{N}$ and $\mathrm{P}$ in plants could increase chlorophyll content and further aid leaf biomass growth. However, the inadequacy of these elements could be detrimental to crops (Adekunle 2014). Plant with a high concentration of $\mathrm{P}$ produces the maximum number of leaves and other shoot biomass. The amount of $\mathrm{K}$ concentration in plants grown in M3 $(1.26 \%)$ was significantly higher $(\mathrm{P}=0.06)$ than that found in plants grown in M1 (1.06\%). Some concentration of calcium and magnesium was found in plants
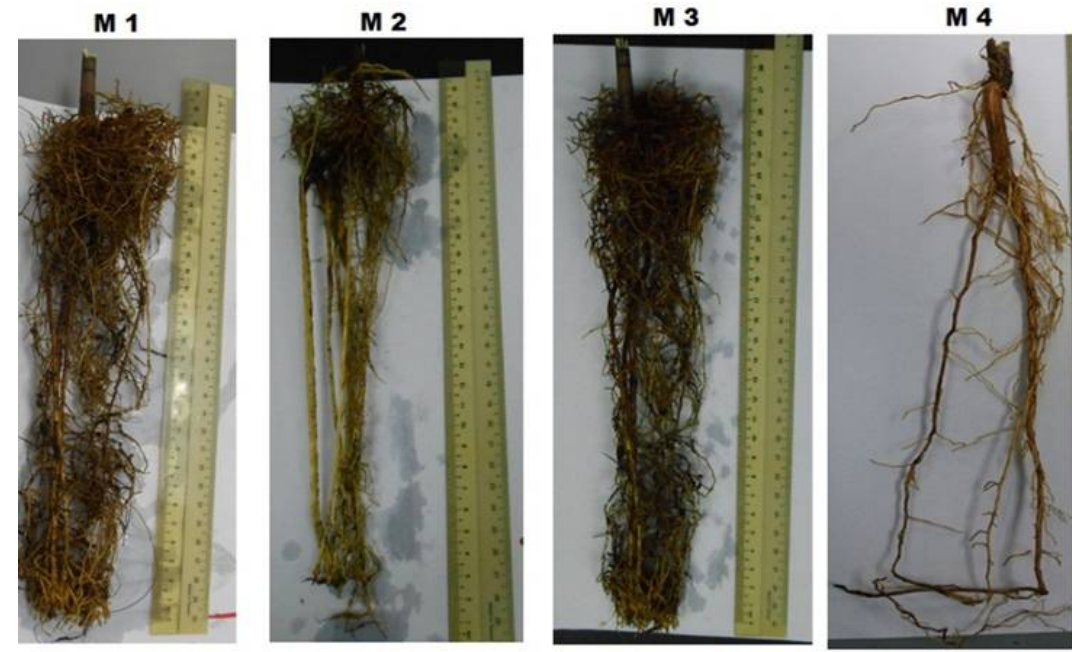

Fig. 1. Root samples of rubber seedlings grown in different soilless media and soil-based medium.

grown in all the growing media except in M4 soil. Apart from nutrients concentration, other factors which could stimulate plant growth and vegetative traits are a better gaseous exchange and improved drainage as well as a uniform extension of root systems. There was a significant difference $(\mathrm{P}=0.04)$ between the seedlings root length as shown in Table 5. Root length of plants grown in M1 $(2158.9 \mathrm{~cm})$ was greater than those in M4 $(251.4 \mathrm{~cm})$. The effect of the respective growing media is shown in Fig. 1. 
Table 5. Root morphological traits of rubber seedlings grown in soilless and soil-based medium.

\begin{tabular}{llllll}
\hline Treatments & $\begin{array}{l}\text { Av. root length } \\
(\mathrm{cm})\end{array}$ & $\begin{array}{l}\text { Av. root } \\
\text { volume }\left(\mathrm{cm}^{3}\right)\end{array}$ & $\begin{array}{l}\text { Av. diameter } \\
(\mathrm{mm})\end{array}$ & $\begin{array}{l}\text { Av. surface } \\
\text { area }\left(\mathrm{cm}^{2}\right)\end{array}$ & $\begin{array}{l}\text { No. of } \\
\text { tips }\end{array}$ \\
\hline M1 & $2158.9 \mathrm{a}$ & 3.87 & 1.02 & $322.62 \mathrm{a}$ & $9030 \mathrm{a}$ \\
M2 & $886.3 \mathrm{ab}$ & 2.75 & 0.97 & $166.72 \mathrm{ab}$ & $2655 \mathrm{~b}$ \\
M3 & $290.1 \mathrm{~b}$ & 1.65 & 0.89 & $55.65 \mathrm{~b}$ & $1145 \mathrm{~b}$ \\
M4 & $251.4 \mathrm{~b}$ & 2.02 & 1.14 & $79.38 \mathrm{~b}$ & $741 \mathrm{~b}$ \\
LSD & 1326 & 2.68 & 0.31 & 179.83 & 5110.7 \\
p > F & 0.04 & 0.29 & 0.34 & 0.038 & 0.024 \\
\hline
\end{tabular}

Mean values followed by the same letter within the same column are not significantly different at $\mathrm{p}<0.05$, based on a least significant difference test (LSD).

The soilless medium M1 which contains less perlite (5\%), profoundly aids root growth. A similar scenario was observed with regards to root surface area wherein plants grown in M1 $\left(322.62 \mathrm{~cm}^{2}\right)$ was significantly $(\mathrm{P}=0.038)$ greater than those in M2 $(166.72), \mathrm{M} 3\left(55.65 \mathrm{~cm}^{2}\right)$ and M4 $\left(79.38 \mathrm{~cm}^{2}\right)$. Furthermore, only M1 significantly influenced the root number of tips (9030) when compared to the plants grown in other growing media. Planting medium, M1 gave the highest plant height, stem diameter and leaf area among other growing media tested. Despite lower urea-N used in M1 compared to other media, it supports almost all the plant biomass yield like shoot fresh weight, root fresh weight, and root dry weight. Soil-based medium, M4 (control) relatively had the lowest $\mathrm{pH}$ and acidic which could immobilize $\mathrm{N}$ content in the plant. Therefore, the growing medium, M1 is recommended for use in nursery plantation especially in the tropics region where some of the soils have been shown to be acidic and negatively impact plant growth.

\section{Acknowledgements}

The authors would like to thank the authorities of the University Putra Malaysia and the Ministry of Science, Technology and Innovation, Malaysia for the research grant, Grant Round Scheme (GP-IPS), No. 2015/9458500 for supporting the research study.

\section{References}

Adekunle SM 2014. Influence of fertilizer rates on growth of selected immature rubber (Hevea brasiliensis Muell. arg) clones grown on two soil series. Thesis, Master of Science, Faculty of Agriculture, Universiti Putra Malaysia.

Abad M, Noguera P, Puchades R, Maquieira A and Noguera V 2002. Physico-chemical and chemical properties of some coconut coir dusts for use as a peat substitute for containerized ornamental plants. Bioresource Techn. 82(3): 241-245.

Blake GR, and Hartge KH1986. Particle density. In: Methods of Soil Analysis: Part 1-Physical and Mineralogical Methods. pp. 377- 382.

Cantliffe DJ, Castellanos JZ and Paranjpe AV 2007. Yield and quality of greenhouse-grown strawberries as affected by nitrogen level in coco coir and pine bark media. Proceedings of Florida State Horticultural Society 120: 157 - 161.

Durham RL 1987. Plant growth media containing rice hull ash. U.S. Patent 4,707,176, issued November 17. 
Dickson A, Leaf AL and Hosner JF 1960. Quality appraisal of white spruce and white pine seedling stock in nurseries. The Forestry Chronicle 36(1): 10-13.

Durner EF, Poling EB, and Maas JL 2002. Recent advances in strawberry plug transplant technology. HortTechnology. 12(4): 545-550.

Hirel B, Bertin P, Quilleré I, Bourdoncle W, Attagnant C, Dellay C and Gallais A 2001. Towards a better understanding of the genetic and physiological basis for nitrogen use efficiency in maize. Plant Physiology 125(3): 1258-1270.

Kim HJ and Li X 2016. Effects of phosphorus on shoot and root growth, partitioning, and phosphorus utilization efficiency in Lantana. HortScience 51(8): 1001-1009.

Mohanan C and Sharma JK 2005. Improvement of the seedling production system in the forestry sector and its impact on seedling health. Kerala Forest Res. Inst. 11: 77-82.

Miyamoto S and Bucks DA 1985. Water quantity and quality requirements of guayule: current assessment. Agric. Water Manag. 10(3): 205-219.

Miller M 2001. Fulfilling special needs of nurseries. BioCycle. 42(4): 55-58.

Noordiana N, Syed Omar, SR, Shamshuddin J and Nik Aziz NM 2007. Effect of organic-based and foliar fertilisers on cocoa (Theobroma cacao L.) grown on an oxisol in Malaysia. Malaysian J. Soil Sci. 11: 29-43.

Noordin WD 2013. Rubber Plantation: Soil Management and Nutritional Requirement. Universiti Putra Malaysia, Serdang: UPM.

Rodriguez JC, Cantliffe DJ, Shaw NL and Karchi Z 2006. Soilless media and containers for greenhouse production of 'Galia' type muskmelon. HortScience 41(5): 1200-1205.

Sharma VK, Godara AK, Kumatkar R 2015. Effect of soilless growing structures on vegetative growth and roots of strawberry cv. Sweet Charlie. The Ecoscan 9(1\&2): 89-91.

Sinclair TR and Vadez V 2002. Physiological traits for crop yield improvement in low N and P environments. Plant and Soil 245(1): 1-15.

Salisu M, Daud N and Ahmad I 2013. Influence of fertilizer rates and soil series on growth performance of natural rubber ('Hevea brasiliensis') latex timber clones. Australian J. Crop Sci. 7(13): 1998 - 2004.

Teh CBS and Jamal T 2006. Soil Physics Analyses. Saturated hydraulic conductivity. Serdang: UPM.

Vieira NCDS, Maruyama WI, Costa E, Dias PM and Pereira AC 2016. Clones, substrates and environments for seedlings of rubber tree rootstocks. Engenharia Agrícola 36(5): 749-759.

Warncke DD 1990. Testing artificial growth media and interpreting the results. In: Soil testing and plant analysis. American Society of Agronomy, USA.

(Manuscript received on 13 December, 2018; revised on 28 June, 2019) 